\title{
PARADIGMA PERKEMBANGAN AKUNTANSI ISLAM
}

\author{
Muhammad Fadhil Junery \\ Sekolah Tinggi Ilmu Ekonomi (STIE) Syariah Bengkalis \\ Email: longfadhil@gmail.com
}

\begin{abstract}
The limitations of the human mind and also the various interests which always refers to the mundane aspects, then all rules in the order of economic and business cannot be released granted to man to design these rules without any ropes of restraint as a means to restrict people from doing arbitrary and more likely just as homo economicus, which is why Islam was present to bring the values of truth and justice which serve as guidance for not only humans as homo economicus but also as homo and homo religious ethicus. Seeing some of the weaknesses and limitations of today's accounting in its development, Require Muslims to dissolve creasing these problems, by making the sharia as a paradigm in building a conceptual framework of accounting that can be used as a foothold in the development of accounting format is more appropriate. And foster the values of the essence in the accounting value of responsible, fair and true.
\end{abstract}

Keywords: Economic and Business, Accounting Sharia, Paradigm, Essential Values in the Accounting, Value of Responsible.

\section{PENDAHULUAN}

Masalah ekonomi dewasa ini dianggap sebagai masalah yang universal, dikarenakan setiap penjuru dunia menaruh perhatiannya pada masalah ekonomi, dapat kita lihat di belahan dunia lain pada saat sekarang masih ada lagi penjajahan (peperangan) atau agresi, walaupun dengan berbagai alasan seperti "Anti Teroris", "Demi Perdamaian Dunia, Teroris Harus Dibumi Hanguskan" dan banyak lagi alasan-alasan yang terucap dari bibir manis para pelaku-pelakunya. Namun pada hakikat yang sebenarnya peperangan tersebut terjadi disebabkan oleh masalah ekonomi.

Melihat begitu pentingnya persoalan ekonomi bagi kehidupan manusia, timbul satu pertanyaan. Apakah persoalan ekonomi yang melanda setiap penjuru dunia ini dapat diselesaikan secara komperhensif? Maka jelas jawabannya adalah tidak. Mengapa? Dapat kita lihat seorang petani ingin membajak sawahnya agar dia bisa menanam padi demi memenuhi kebutuhan untuk kesejahteraan dan kelangsungan hidup si petani dan keluarganya, namun si petani bukannya bajak sawah yang dibawa melainkan sebilah parang, walaupun parang juga dapat digunakan untuk menggemburkan tanah persawahan tetapi kurang tepat sehingga mengakibatkan banyak terjadinya kerugian terutama tenaga dan waktu. Begitu juga dengan persoalan ekonomi yang terjadi dewasa ini tidak dapat diselesaikan secara komperhensif karena sistem, teori serta strateginya tidak teratur dan tidak relevan serta tidak menyeluruh. 
Dalam kancah perkembangan peradaban umat manusia, sebenarnya Islam telah memberikan konstribusi yang paling besar. Akan tetapi, kenyataan sekarang masyarakat Islam jauh ketinggalan dibandingkan masyarakat Barat. Dapat dilihat dari bidang ekonomi, masyarakat Islam atau Negara-negara Islam berada pada tingkat menengah ke bawah.

Agama Islam adalah agama yang sangat memperhatikan masalah pembangunan ekonomi dan mendorong penganutnya berjuang untuk mendapatkan materi/harta dengan berbagai cara, asalkan sesuai dengan patokanpatokan/rambu-rambu yang telah ditetapkan, antara lain (Manan 1992, 65):

1. Carilah yang halal lagi baik;

2. Tidak menggunakan cara batil;

3. Tidak berlebih-lebihan/melampaui batas;

4. Tidak didzalimi maupun mendzalimi;

5. Menjauhkan diri dari unsur riba, maisir (perjudian dan intendet speculation) dan gharar (ketidak jelasan dan manipulatif)

6. Tidak melupakan tanggungjawab sosial berupa zakat, infaq dan shadaqah.

Hal yang harus kita ketahui bahwa Islam itu lebih integral dari sekedar agama. Islam adalah agama dan dunia, ibadah dan mua'malah, aqidah dan syariah, kebudayaan dan peradaban serta agama dan negara. (Qardhawi 1997, 17)

Seperti yang dikatakan (Shopiaan 1997, 5) bahwa perkembangan dunia dewasa ini dan beberapa dekade mendatang tampaknya masih akan didominasi dengan persoalan ekonomi. Terlebih lagi sejak usainya perang dingin, perkembangan dunia selanjutnya praktis diwarnai ketegangan ekonomi antara Blok Selatan yang mayoritas adalah Negara-negara yang berkembang (miskin) dengan Blok Utara yang merupakan Negara-negara industri maju.

Instrumen-instrumen ekonomi yang bernafaskan Islam banyak bermunculan, penelitian dan diskusi-diskusi ekonomi islam termasuk bidang akuntansi syariah telah menjalar kesetiap penjuru dunia. Karena akuntansi merupakan hal penting dalam bisnis ini dikarenakan dalam pengambilan seluruh keputusan bisnis didasarkan informasi yang diperoleh dari akuntansi.

Tujuan akuntansi syariah berdasarkan pada tujuan ekonomi islam, yaitu pemerataan kesejahteraan bagi seluruh umat (Kusumawati 2005, 16). Akuntansi syariah juga menjadi sarana memberikan informasi kepada pihak internal dan eksternal. Firman Allah SWT pada QS. Al-An'am (6): 165 (Depag RI 1971):

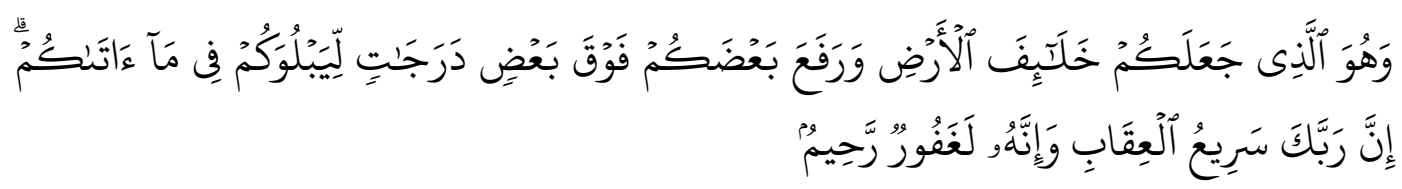

Artinya: "Dan Dia-lah yang menjadikan kamu penguasa-penguasa di bumi dan Dia meninggikan sebagian kamu atas sebagian yang lain beberapa derajat untuk mengujimu tentang apa yang diberikan-Nya kepadamu. Sesungguhnya Tuhanmu sangat cepat memberi hukuman dan sungguh Dia Maha Pengampun, Maha Penyayang ".

Berdasarkan ayat tersebut, maka tujuan akuntansi syariah adalah pertanggungjawaban (Accountability), baik pertanggungjawaban terhadap Allah, pihak-pikak yang berhak atas perusahaan, maupun alam. 


\section{NILAI-NILAI ISLAM DALAM AKUNTANSI}

Persoalan akuntansi sebenarnya bukan hal yang baru bagi umat islam, ini dikarenakan Allah SWT telah menjelaskan didalam Al-Quran Surah Al-Baqarah (2): 282 (Depag RI 1971):

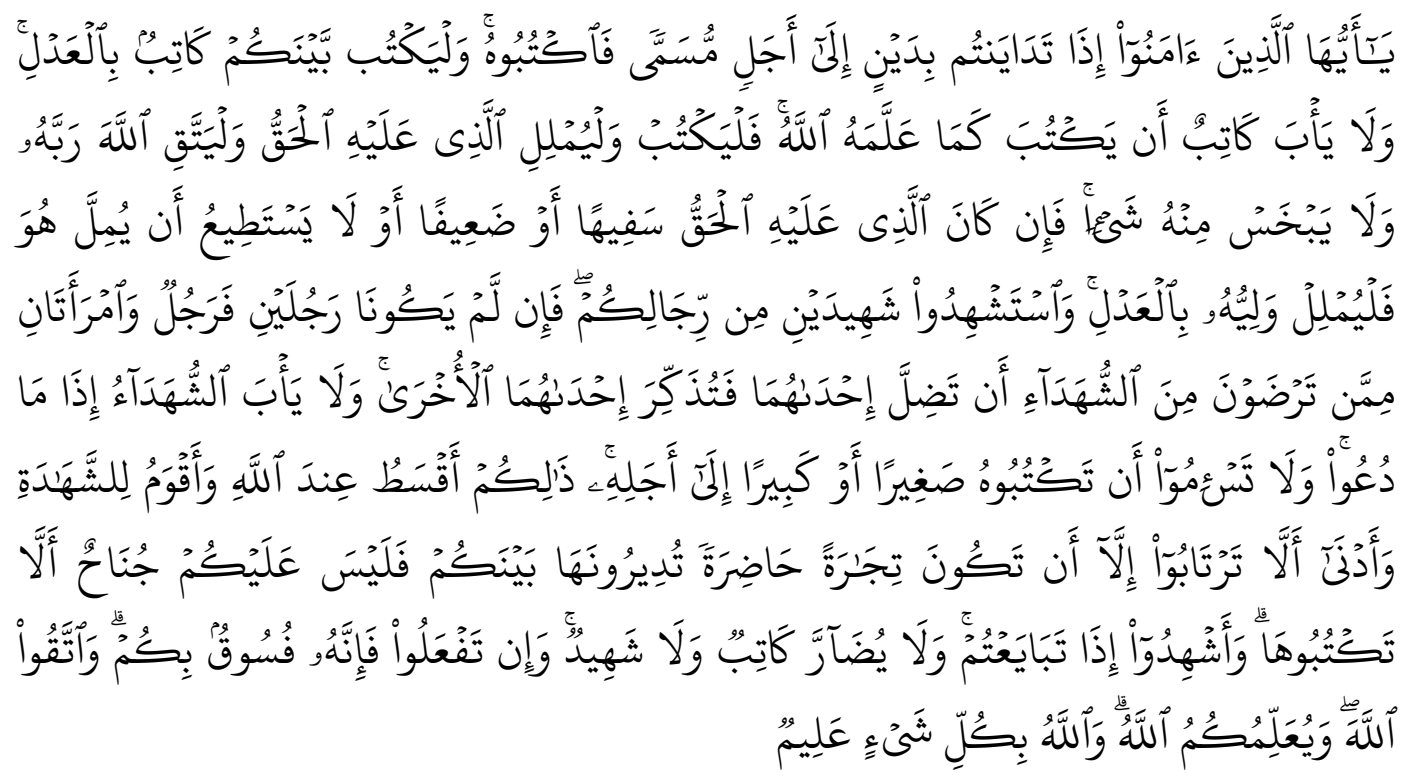

Artinya: "Hai orang-orang yang beriman, apabila kamu bermu'amalah tidak secara tunai untuk waktu yang telah ditentukan, hendaklah kamu menuliskannya. Dan hendaklah seorang penulis diantara kamu menuliskannya dengan benar. Dan janganlah penulis tidak mau menuliskannya sebagaimana Allah telah mengajarkannya, maka hendaklah ia menulis dan hendaklah orang yang berhutang itu mengimlakkan (apa yang akan ditulis itu) dan hendaklah ia bertakwa kepada Allah Tuhannya, dan janganlah ia mengurangi sedikit pun daripada hutangnya. Jika yang berhutang itu orang yang lemah akalnya atau lemah (keadaannya) atau dia sendiri tidak mampu mengimlakkan, maka hendaklah walinya mengimlakkan dengan jujur. Dan persaksikanlah dengan dua orang saksi dari orang laki-laki diantaramu. Jika tidak ada dua orang laki-laki, maka (boleh) seorang laki-laki dan dua orang perempuan dari saksi-saksi yang engkau ridhai, supaya jika seorang lupa maka seorang lagi mengingatkannya..."

Tujuan perintah ayat tersebut adalah untuk menjaga keadilan dan kebenaran, artinya perintah tersebut ditekankan pada kepentingan pertanggungjawaban agar pihak-pihak yang terlibat dalam transaksi itu tidak dirugikan, sehingga tidak menimbulkan konflik dan untuk menciptakan transaksi yang adil maka diperlukan saksi. Dari ayat tersebut, maka lahirlah konsep akuntansi syariah yang sarat dengan nilai-nilai islam (Al-Quran dan Al-Hadist). Ada beberapa pendapat tentang definisi akuntansi, di antaranya (Harahap 2001, 27-28):

1. Menurut Littleton, tujuan utama dari akuntansi adalah "melaksanakan perhitungan periodic antara biaya (usaha) dan hasil (prestasi). Konsep ini merupakan inti dari teori akuntansi dan merupakan ukuran yang dijadikan sebagai rujukan dalam mempelajari akuntansi”.

2. APB (Accounting Principle Board) Statement No. 4 mendefinisikan sebagai berikut: "Akuntansi adalah suatu kegiatan jasa. Fungsinya adalah memberikn 
informasi kuantitatif, umumnya dalam ukuran uang, mengenai suatu badan ekonomi yang dimaksud untuk digunakan dalam mengambil keputusan ekonomi, yang digunakan dalam memilih di antara beberapa alternatife".

3. AICPA (American Institute of Certified Public Accountant) mendefinisikan sebagai berikut: "Akuntansi adalah seni pencatatan, penggolongan dan pengikhtisaran dengan cara tertentu dan dalam ukuran moneter, transaksi dan kejadian-kejadian yang umumnya bersifat keuangan dan termasuk penafsiran hasil-hasilnya".

4. Dalam buku A Statement of Basic Accounting Theory dinyatakan bahwa akuntansi adalah "Proses mengidentifikasi, mengukur dan menyampaikan informasi ekonomi sebagai bahan informasi dalam hal pertimbangan dalam mengambil kesimpulan oleh para pemakainya".

Akuntansi syariah, secara sederhana dapat didefinisikan sebagai akuntansi yang konsep dan pratiknya dibangun sesuai dengan sendi syariah Islam. Akuntansi tidak bisa dilepaskan begitu saja pembangunan dan pengembangannya kepada kemampuan sekaligus keterbatasan akal budi manusia dan juga berbagai kepentingan yang selalu mengacu pada aspek duniawi. Dan sebagai salah satu alat dalam melakukan kegiatan bisnis, maka akuntansi juga tidak boleh terlepas dari nilai-nilai bisnis yang dibolehkan atau yang telah diatur oleh Islam. (Adnan 2005, 140)

Peranan syariah bagi aplikasi akuntansi dalam masyarakat muslim sangat besar, terutama karena syariah merupakan etika bagi orang muslim. Syariah sendiri bertujuan untuk meningkatkan kesejahteraan masyarakat dengan menjamin kepercayaan, kehidupan, kecerdasan, keturunan dan kesejahteraan (Triyuwono 2001, 25). Perkembangan ilmu mengenai akuntansi dalam masyarakat muslim akhirnya muncul suatu bentuk akuntansi yaitu akuntansi yang berlandaskan syariah Islam, biasa disebut dengan akuntansi syariah atau akuntansi Islam. Dimana akuntansi syariah berbeda dengan akuntansi konvensional yakni akuntansi yang lahir dari budaya kapitalistik yang menggunakan prinsip Self Interst (kepentingan pribadi) sebagai dasar perumusan konsep ekonominya (Abdad 2003, 56).

Prinsip akuntansi syariah tidak terlepas dari nilai-nilai yang menjadi prinsip dasar yang universal dalam akuntansi syariah, yakni nilai pertanggungjawaban (Accountability), keadilan dan kebenaran (Muhammad 2005, 11). Adapun makna yang terkandung dalam tiga nilai tersebut yang terdapat dalam Al-Quran Surah Al-Baqarah: 282, sebagai berikut (Muhammad 2000, 42):

1. Nilai Pertanggungjawaban (Accountability).

Nilai pertanggungjawaban merupakan konsep yang tidak asing lagi di kalangan masyarakat muslim. Pertanggungjawaban selalu berkaitan dengan konsep amanah. Bagi masyarakat muslim, persoalan amanah merupakan hasil transaksi manusia dengan sang Khaliq mulai dari alam kandungan. Manusia diberi amanah oleh Allah untuk menjalankan fungsi-fungsi kekhalifahannya. Implikasi dalam bisnis dan akuntansi adalah bahwa individu yang terlibat dalam praktik bisnis harus selalu melakukan pertanggungjawaban terhadap apa yang telah diamanahkan dan diperbuat kepada pihak-pihak yang terkait. Wujud pertanggungjawaban biasanya dalam bentuk laporan akuntansi.

2. Nilai Keadilan 
Keadilan tidak hanya merupakan nilai yang sangat penting dalam etika kehidupan sosial dan bisnis, tetapi juga merupakan nilai yang secara inheren melekat dalam fitrah menusia.

Dalam konteks akuntansi, nilai keadilan secara sederhana dapat berarti bahwa setiap transaksi yang dilakukan oleh individu atau organisasi harus dicatat dengan benar. Dengan kata lain, tidak ada Window Dressing dalam praktik pelaporan akuntansi. Dengan demikian, kata keadilan dalam konteks aplikasi akuntansi mengandung dua pengertian, yaitu : Pertama, berkaitan dengan praktik moral, yaitu kejujuran yang merupakan faktor yang sangat dominant. Tanpa kejujuran, informasi akuntasi yang disajikan akan menyesatkan dan sangat merugikan bagi pengguna informasi. Kedua, kata adil bersifat lebih fundamental tetapi tetap berlandaskan pada nilai-nilai syariah. Pengertian kedua ini lebih cenderung sebagai pendorong untuk melakukan upaya-upaya dekontruksi terhadap bangun akuntansi modern kepada bangun akuntansi (alternatif) yang lebih baik.

3. Nilai Kebenaran.

Nilai kebenaran sebenarnya tidak terlepas dari nilai keadilan. Seperti halnya dalam akuntansi kita akan selalu dihadapkan pada masalah pengakuan, pengukuran dan pelaporan. Aktivitas ini akan dapat dilakukan dengan baik apabila dilandaskan dengan prinsip kebenaran. Dimana kebenaran akan dapat menciptakan keadilan dalam mengakui, mengukur dan melaporkan transaksitransaksi ekonomi.

Aplikasi akuntansi secara bertanggungjawab, adil dan benar merupakan nilai yang esensian dalam akuntansi, hal ini seiring dengan perkembangan ekonomi dan bisnis, sehingga banyak hal-hal yang harus disesuaikan, dengan tetap mempertahankan sifat teknis dalam memberi informasi yang relevan dan terpecaya.

\section{PARADIGMA AKUNTANSI SYARIAH}

Akhir-akhir ini kajian dibidang akuntansi dalam perspektif Islam atau akuntansi syariah mengalami peningkatan, hal ini dikarenakan dengan banyaknya bermunculan sistem perbankan syariah, dimana aspek-aspek akuntansi konvensional tidak dapat diterapkan pada lembaga yang menggunakan prinsipprinsip syariah. Hal ini juga tidak terlepas dari kebutuhan akan rasionalitas kerangka konseptual pelaporan keuangan perbankan syariah.

Nilai sosial dan ekonomi yang berlaku dalam masyarakat sangat berhubungan erat dengan akuntansi. Perubahan-perubahan yang terjadi dalam masyarakat baik peradaban maupun kehidupan sosial, akan mempengaruhi perubahan dalam sifat akuntansi.

Pengenalan beberapa konsep dan nilai yang paling mendasar pada akuntansi konvensional sangat bersifat kontradiksi bagi masyarakat Islam. Karena secara mendasar konsep dan nilai tersebut berhubungan dengan bunga atau riba. Riba adalah sesuatu yang diharamkan dalam Islam.

Secara umum dapat dikatakan, bahwa masalah rasionalisme sebagai suatu dasar dalam pengembangan akuntansi saat ini yang didalamnya terdapat tiga gambara kontradiktif menurut pandangan islam, yaitu (Muhammad 2000, 64): 
1. Akuntansi konvensional didasari oleh penolakan agama dan metafisika serta menempatkan Negara sebagai kekuatan yang berkuasa. Hal ini bertentangan dengan konsep islam, dimana syariah merupakan sesuatu kekuatan petunjuk yang mengarahkan seluruh aspek kehidupan manusia dan mempertanggungjawabkan secara penuh kepada Tuhan.

2. Kepercayaan dan nilai dasar akuntansi konvensional yang berdasarkan pada konsep kepentingan pribadi tanpa memperdulikan kepentingan sosial.

3. Akuntansi konvensional mempercayai bahwa manusia tidak memilik konsepsi inheren mengenai keadilan tetapi manusia memiliki sifat pengambil peluang.

Dari ketiga pandangan diatas dapat diambil kesimpulan bahwa akuntansi konvensional malihat manusia cenderung sebagai homo economicus, sedangkan dalam Islam, manusia tidak hanya sebagai homo economicus tetapi juga sebagai homo ethicus dan homo religius. Berdasarkan keterbatasan inilah, maka perlu dipikirkan paradigma alternatif yang mengandung aspek baik teknik maupun sosial yang berdasarkan rasionalitas dengan mempertimbangkan agama serta dapat menyelaraskan antara kepentingan pribadi dengan kepentingan sosial.

Melihat keberadaan akuntansi konvensional memiliki beberapa kelemahan dan keterbatasan menurut pandangan masyarakat Islam, untuk meleraikan kekusutan problema tersebut, maka diusulkanlah syariah sebagai dasar dalam membangun kerangka konseptual akuntansi yang dapat dijadikan pijakan dalam pengembangan format akuntansi yang lebih sesuai.

Dalam hal ini, masyarakat muslim menilai bahwa syariah dapat menjadi paradigma yang sesuai untuk pengembangan akuntansi syariah. Dasar-dasar paradigma syariah dapat dilihat pada Gambar 1 di bawah ini:

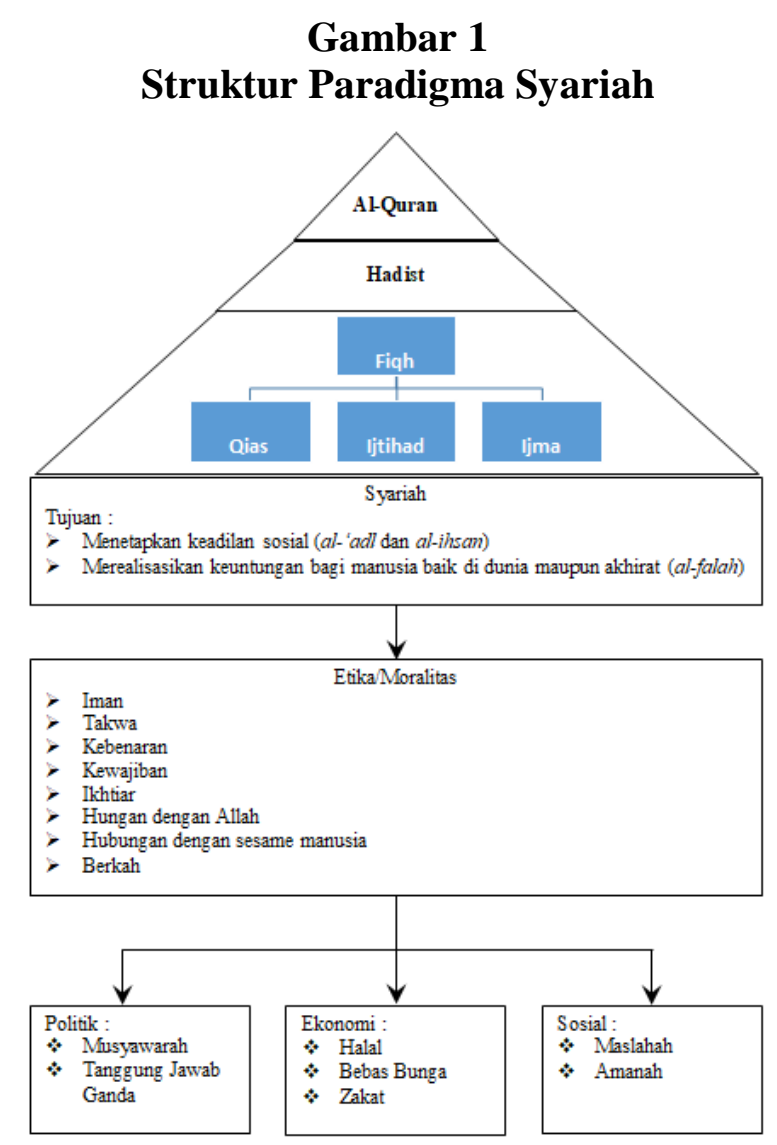


Paradigma tersebut menggambarkan bahwa syariah diturunkan dari tiga sumber, yaitu: Al-Quran, Al-Hadist dan Fiqh. Sumber-sumber tersebut secara hirarki tidak dapat didahulukan antara satu sumber dengan sumber yang lain. Tujuan syariah adalah mendidik setiap manusia, memantapkan keadilan dan merealisasikan keuntungan bagi setiap manusia di dunia maupun akhirat. Syariah berkaitan erat dengan peningkatan keadilan dan kesejahteraan masyarakat, dengan menjadikan aspek moral, sosial, politik dan filsafat ekonomi sebagai pondasi.

Dalam Islam, aspek moral ditopang dengan konsep tauhid, iman dan konsep kebenaran, ketaqwaan, ibadah, kewajiban dan ikhtiar. Ajaran Islam mengatakan bahwa aktivitas ekonomi atau bisnis merupakan bentuk ibadah. Selanjutnya dalam menjalankan aktivitas ekonomi dan bisnis harus diawali dengan akad yang jelas, melakukan pencatatan disetiap transaksi, tidak berlebihan dan memenuhi kewajiban kepada masyarakat dengan membayar zakat. Dalam melakukan aktivitas ekonomi dan bisnis diperintahkan bagi setiap muslim untuk menjauhkan aktivitas yang dilarang syariah dan semua bentuk spekulatif dalam transaksi bisnis. Hal ini bertujuan untuk dapat terciptanya keadaan ekonomi yang adil dengan berdasarkan pada kebersamaan dan transparasi.

\section{KONSEPTUAL AKUNTANSI SYARIAH}

Kemajuan dan perkembangan akuntansi syariah saat ini semakin dibutuhkan, bukan hanya dari sudut tehnik dan standar akuntansi, namun dalam hal filsafat dan ontology ilmu akuntansi juga dibutuhkan. Hal ini dikarenakan tanpa filsafat dan ontology ilmu akuntansi, maka standar akuntansi syariah tidak lebih hanya merupakan upaya tambal sulam akuntansi konvensional yang tongkat dasarnya tetap kapitalis.

Kehadiran akuntansi syariah tidak perlu diragukan lagi, karena kehadiranya memberikan benang merah terhadap persoalan yang selama ini menjadi teka-teki bagi para pelaku ekonomi yang menjadi korban ketidak adilan dan ketidak transparannya informasi keuangan, serta spekulasi dalam transaksitransaksi yang banyak ditemukan dalam sistem akuntansi konvensional.

Terdapat tiga dimensi dalam paradigma akuntansi syariah yang saling berkaitan, yakni:

1. Mencari keridhoan Allah SWT sebagai tujuan utama dalam menentukan keadilan sosio-ekonomi;

2. Merealisasikan keuntungan bagi masyarakat, yaitu dengan memenuhi kewajiban kepada masyarakat; dan

3. Mengejar kepentingan pribadi, yaitu memenuhi kebutuhan sendiri.

Akuntansi Syariah harus ikut serta dalam menciptakan keadilan sosioekonomi dan ini merupakan bagian dari ibadah. Karena etika Islam didukung oleh konsep tauhid, iman, kebaikan, ketaqwaan, ibadah, kewajiban, ikhtiar, hubungan dengan Allah, hubungan dengan manusia dan berkah. Dalam upaya Akuntansi syariah menciptakan keadilan sosio-ekonomi, maka aspek teknis dan aspek manusianya harus berjalan seiring dalam melaksanakan peranannya dengan berpedomankan syariah. Dimana peranan aspek teknis yang berkaitan dengan kontruksi akuntansi syariah dalam melakukan pengukuran dan pengungkapan, sedangkan aspek manusianya mempunyai peranan yang menyangkut kekuasaan 
dan penerapannya. Site Plan Konseptual Akuntansi Syariah tersebut dapat dilihat pada Gambar 2 di bawah ini:

Gambar 2

Site Plan Konseptual Akuntansi Syariah

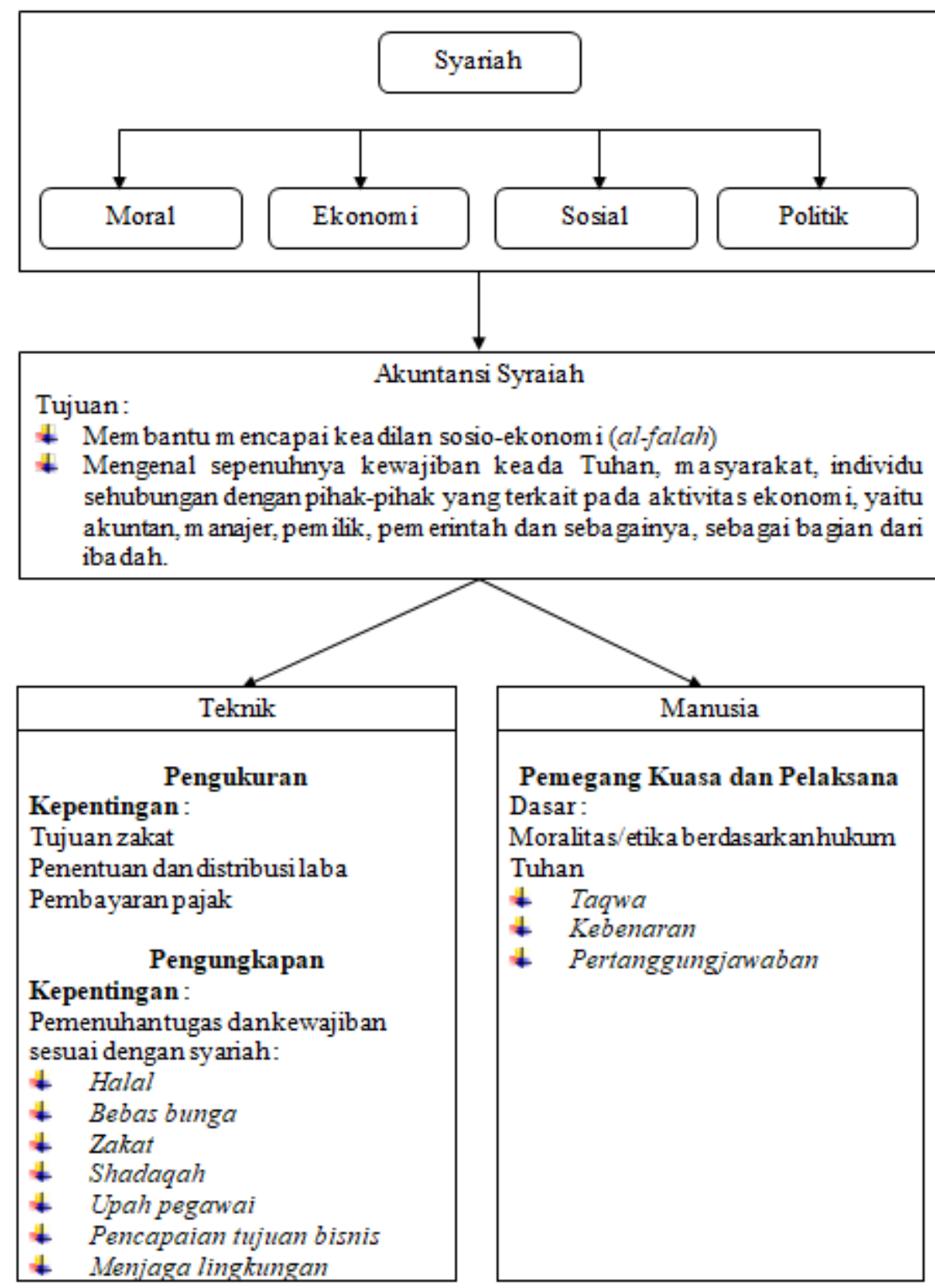

\section{PENUTUP}

Sistem akuntansi syariah jauh berbeda dengan sistem akuntansi yang ada. Dimana sistem akuntansi mempunyai dasar filosofi yang mempunyai keseimbangan antara kepentingan individu dengan kepentingan masyarakat yang dibangun atas dasar syariah.

Implikasi praktis dari sistem ekonomi Islam telah ditemukan dan diformulasikan, yaitu dengan mulai beroperasionalnya lembaga-lembaga 
keuangan umat (Islam). Persoalannya sekarang adalah mampukah lembaga keuangan umat tersebut dapat meralisasikan nilai filosofi yang merupakan normatif dari sistem ekonomi Islam yang diperkuat dengan menerapkan sistem akuntansi syariah.

\section{DAFTAR PUSTAKA}

Abdad, M. Zaidi. 2003. Lembaga Perekonomian Umat Di Dunia Islam. Bandung: Angkasa.

Adnan, M. Akhyar. 2005. Akuntansi Syariah: Arah, Prospek dan Tantangannya, Cetakan II. Yogyakarta: UII Press.

Depdikbud. 1994. Kamus Besar Bahsa Indonesia. Jakarta: Balai Pustaka.

Depertemen Agama RI. 1971. Al-Quran dan Terjemahannya, Sumbangan dari Khadim Al-Haramain Asy-Syarifain (Pelayan kedua Tanah Suci) Raja Fadh Ibn 'Abd Al-Aziz, Al-Sa'ud. Jakarta.

Harahap, Sofyan Syafri. 2001. Akuntansi Islam, Cetakan III. Jakarta: Bumi Aksara.

Kusumawati, Zaidah. 2005. Menghitung Laba Perusahaan: Aplikasi Akuntansi Syariah, Cetakan I. Yogyakarta: Magistra Insani Press.

Manan, M.A. 1992. Islamic Economic: Theory and Practice, alih bahasa: Potan Arif Harahap, Ekonomi Islam: Teory dan Praktek. Jakarta: Intermasa.

Muhammad. 2005. Pengantar Ekonomi Syariah, Edisi II. Jakarta: Salemba Empat.

Muhammad. 2000. Prinsip-prinsip Akuntansi dalam Al-Quran. Yogyakarta: UII Press.

Shopiaan, Ainur R. 1997. Etika Ekonomi Politik: Elemen-elemen Strategis Pembangunan Masyarakat Islam, Surabaya: Risalah Gusti.

Triyuwono, Iwan dan Moh. As'udi. 2001. Akuntansi Syariah: Memformulasikan Konsep Laba dalam Konteks Metaforma Zakat, Edisi I. Jakarta: Salemba Empat.

Qardhawi, Yusuf. 1997. Daurul Qiyam wal Akhlaq fil Iqtishodil Islami, penterjemah: Didin Hafidhuddin, Setiawan Budi Utomo dan Aunur Rofiq S.T. Peran Nilai dan Moral dalam Perekonomian Islam, Cetakan I. Jakarta: Robbani Press. 